Original Article

\title{
A comparative assessment of air pollutants of smog in wagah border and other sites in Lahore, Pakistan
}

\author{
Uma avaliação comparativa de poluentes do ar do smog na fronteira de wagah e outros \\ sites em Lahore, Paquistão
}

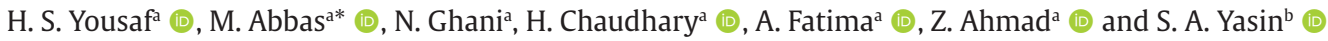 \\ aLahore College of Women University, Department of Environmental Science, Jail Road, Lahore, Pakistan \\ 'Lahore College of Women University, GDS Department, Jail Road, Lahore, Pakistan
}

\begin{abstract}
Smog has become the fifth season of Pakistan especially in Lahore city. Increased level of air pollutants (primary and secondary) are thought to be responsible for the formation of smog in Lahore. Therefore, the current study was carried out for the evaluation of air pollutants (primary and secondary) of smog in Wagah border particularly and other sites (Jail road, Gulburg) Lahore. For this purpose, baseline data on winter smog from March to December on primary and secondary air pollutants and meteorological parameters was collected from Environmental Protection Department and Pakistan Meteorological Department respectively. Devices being used in both departments for analysis of parameters were also studied. Collected data was further statistically analyzed to determine the correlation of parameters with meteorological conditions and was subjected to air quality index. According to results, PM 10 and PM 2.5 were found very high above the NEQS. NOx concentrations were also high above the permissible limits whereas $\mathrm{SO}_{2}$ and $\mathrm{O}_{3}$ were found below the NEQS thus have no roles in smog formation. Air Quality Index (AQI) of pollutants was PM 2.5(86-227), PM 10 (46-332), NOx (26-110), $\mathrm{O}_{3}$ (19-84) and $\mathrm{SO}_{2}(10-95)$. AQI of PM 2.5 remained between moderate to very unhealthy levels. AQI of PM 10 remained between good to hazardous levels. AQI of NOx remained between good to unhealthy for sensitive groups' levels. AQI of $\mathrm{O}_{3}$ and $\mathrm{SO}_{2}$ remained between good to moderate levels. Pearson correlation showed that every pollutant has a different relation with different or same parameters in different areas. It is concluded from the present study that particulate matter was much more responsible for smog formation. Although NOx also played role in smog formation. So there is need to reduce sources of particulate matter and NOx specifically in order to reduce smog formation in Lahore.
\end{abstract}

Keywords: Smog, PM2.5, PM10, Wagah border, air pollutants.

\begin{abstract}
Resumo
Smog tornou-se a quinta estação do Paquistão, especialmente na cidade de Lahore. Acredita-se que o aumento do nível de poluentes atmosféricos (primários e secundários) seja responsável pela formação de poluição atmosférica em Lahore. Portanto, o presente estudo foi realizado para a avaliação dos poluentes atmosféricos (primários e secundários) do smog na fronteira de Wagah em particular e em outros locais (Jail road, Gulburg) Lahore. Para este propósito, os dados de referência sobre a poluição atmosférica de inverno de março a dezembro sobre poluentes atmosféricos primários e secundários e parâmetros meteorológicos foram coletados do Departamento de Proteção Ambiental e do Departamento Meteorológico do Paquistão, respectivamente. Dispositivos sendo usados em ambos os departamentos para análise de parâmetros também foram estudados. Os dados coletados foram posteriormente analisados estatisticamente para determinar a correlação dos parâmetros com as condições meteorológicas e foram submetidos ao índice de qualidade do ar. De acordo com os resultados, PM 10 e PM 2,5 foram encontrados muito acima do NEQS. As concentrações de NOx também estavam muito acima dos limites permitidos, enquanto $\mathrm{SO}_{2}$ e $\mathrm{O}_{3}$ foram encontrados abaixo do NEQS, portanto, não têm papéis na formação de $s m o g$. $\mathrm{O}$ índice de qualidade

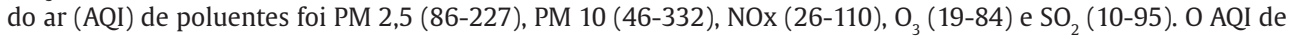
PM 2,5 permaneceu entre níveis moderados a muito prejudiciais à saúde. O AQI de PM 10 permaneceu entre níveis bons e perigosos. AQI de NOx permaneceu entre bom e não saudável para os níveis de grupos sensíveis. O AQI de $\mathrm{O}_{3}$ e $\mathrm{SO}_{2}$ permaneceu entre níveis bons a moderados. A correlação de Pearson mostrou que cada poluente tem uma relação diferente com parâmetros diferentes ou iguais em áreas diferentes. Conclui-se do presente estudo que o material particulado foi muito mais responsável pela formação de smog. Embora o NOx também tenha desempenhado um papel na formação do smog. Portanto, é necessário reduzir as fontes de partículas e NOx, especificamente para reduzir a formação de smog em Lahore.
\end{abstract}

Palavras-chave: poluição atmosférica, PM2.5, PM10, fronteira Wagah, poluentes atmosféricos.

*moneeza.rana@gmail.com

Received: May 22, 2021 - Accepted: September 2, 2021

This is an Open Access article distributed under the terms of the Creative Commons Attribution License, which permits unrestricted use, distribution, and reproduction in any medium, provided the original work is properly cited. 


\section{Introduction}

Air pollution has been increasing in both developed and developing countries since industrialization and urbanization. Swiftly increase in traffic volume also a major cause to damage the global ecosystem and environmental degradation. Vehicles are the major contributor of PM2.5 and PM10 pollution which have hazardous effects on air quality and the health of human beings (Abbas et al., 2017). Air pollution is in the form of point source such as Sulphur dioxide $\left(\mathrm{SO}_{2}\right)$, hydrogen fluoride, non-point sources such as carbon monoxide, oxide of nitrogen, hydrocarbons, regional source like ozone-depletion, chlorofluorocarbon and continuous source like emission from electric power plants, municipal waste treatment plants and other secondary pollutants harmfully affect to population health and a main cause to deteriorate ecosystem of the world. According to the World Bank's report transport essentially contributes to air pollution and is one of the most serious threats for public health in Pakistan (Sánchez-Triana et al., 2013). The total population of Punjab with the growth rate of $2.64 \%$ is about 73 million. It is the most densely populated province of Pakistan and has a population density of 358.5 people per square kilometer moreover about 31 percent of its population resides in urban centers where as rest lives in rural areas (Tanveer et al., 2015).

Currently, Globe is getting alarmed by smog. Air pollution with fog leading to smog. Due to Ground level ozone and fine particles are released in the air leads to smog. The primary air pollutants $\left(\mathrm{CO}, \mathrm{NO}_{\mathrm{x}}, \mathrm{PM} 10, \mathrm{PM}\right.$ 2.5 and $\mathrm{SO}_{2}$ ) and secondary air pollutants assorted with meteorological factors (Temperature, Humidity, Wind) forming the smog. With substantial evidences, Particulate Matter and $\mathrm{O}_{3}$ with $\mathrm{NO}_{2}$ are identified as major risk factors for smog. Smog is creating the top most consequences in an environment and health. It may lead to Smog disasters like London's great smog of 1952 (Davis et al., 2002)

During winters, in past few years, widespread fog has frequently occurred in northern India and northeastern part of Pakistan, in a region extending over hundreds of Kilometers (km). Northeastern India and the neighboring sections of Punjab in Pakistan have been under the influence of a high-pressure system, during winters, resulting in dry weather and low wind speed. These conditions are ideal for accumulation of pollutants in the atmosphere (Hameed et al., 2000).

Recently many cities of Pakistan have been struck by the havoc of smog. Smog is formed when pollutants like nitrogen oxide, carbon monoxide and volatile organic compounds that are released from automobiles, industries and burning of fossil fuels interact with sunlight. These photochemical reactions usually occur in summers and leads to the development of ground level ozone or bad ozone $\left(\mathrm{O}_{3}\right)$ which is an important smog causing pollutant. This ozone adversely affects human health especially respiratory and cardiovascular system and is among the cause of premature deaths (Garelnabi et al., 2013).

Pakistan is the most urbanized country in South Asia, and its second-largest city Lahore, growing at a rate of $4 \%$ annually, is regarded as the most polluted city in Pakistan.
Urban settlements are frequently plagued by smog in Asia, and Lahore is no exception (Sánchez-Triana et al., 2014). Smog accounts for a rapid sprout in fatal health problems, including exacerbation of asthma, allergies, eye infections, respiratory tract infections, and cardiac pathologies leading to premature death (Sughis et al., 2012)

The air quality index of Pakistan falls into the category of "unhealthy" air pollution level. Pakistan also saw the number of deaths attributable to $\mathrm{PM}_{2.5}$ exposures for all ages and sexes increase from 82,300 in year 1990 to 135,100 in year 2015 and deaths from chronic obstructive pulmonary disease (COPD) attributable to ozone exposure increase from 1,600 in 1990 to 5,000 in 2015 (Mukhtar, 2018). The current research is an attempt for evaluation of air pollutants of smog in Lahore so that appropriate measures can be taken to reduce emissions or to prevent from this alarming situation.

The objectives of the research work were: i) Collection of primary data on primary and secondary air pollutants in the ambient air of Lahore. ii) Evaluation of seasonal variations of primary and secondary pollutants. iii) Study the correlation of prevalence of air pollutants (primary and secondary) of smog with meteorological conditions. iv) Determination of Air Quality Index for all primary and secondary pollutants from March to December.

\section{Materials and Methods}

The Study was conducted for the assessment of air quality for evaluation of air pollutants of smog specifically in Wagah border and 2 other sites (Jail road and Gulburg). For this purpose, baseline data related to air pollution was collected. Wagah town Lahore was taken as it is the border between Pakistan and India claiming transboundary air pollution, caused by cross border field fires and abysmal environmental conditions in India and exposure of past data of Wagah town on Air Quality Index (AQI) and by satellite imaging (Figure 1). The level of air pollution at Wagah is double than the Lahore city. In Lahore air quality mainly deteriorates during the winter season from October to December when farmers in the wider Punjab province set light to the remnants of crops, making smoke that adds to smog and weather changes at that time, the mean pollutants remain stuck in the air for longer, claiming the major causes of smog in Lahore. Jail road and Gulberg was selected because of their residential and commercial. The city of Lahore $\left(31^{\circ} 15^{\prime}-31^{\circ} 45^{\prime} \mathrm{N}\right.$ and $\left.74^{\circ} 01^{\prime}-74^{\circ} 39^{\prime} \mathrm{E}\right)$ is the provincial capital of Punjab and the second largest city in Pakistan. The city district experiences a hot, semi-arid climate with an average temperature of $24.3^{\circ} \mathrm{C}$ (Rasheed et al., 2015). During the extremely hot summers, the maximum average temperature ranges between 33 and $39^{\circ} \mathrm{C}$ and the minimum averages between 22 and $28{ }^{\circ} \mathrm{C}$, while in winters the average temperature ranges between 15 to $22^{\circ} \mathrm{C}$.

The methodology for the collection and mass determination of particulate matter at Wagah and other sites is rather simple. Air is drawn from the study areas through a size-selective inlet and through some sort of filter media. Particulates with aerodynamic diameters less 


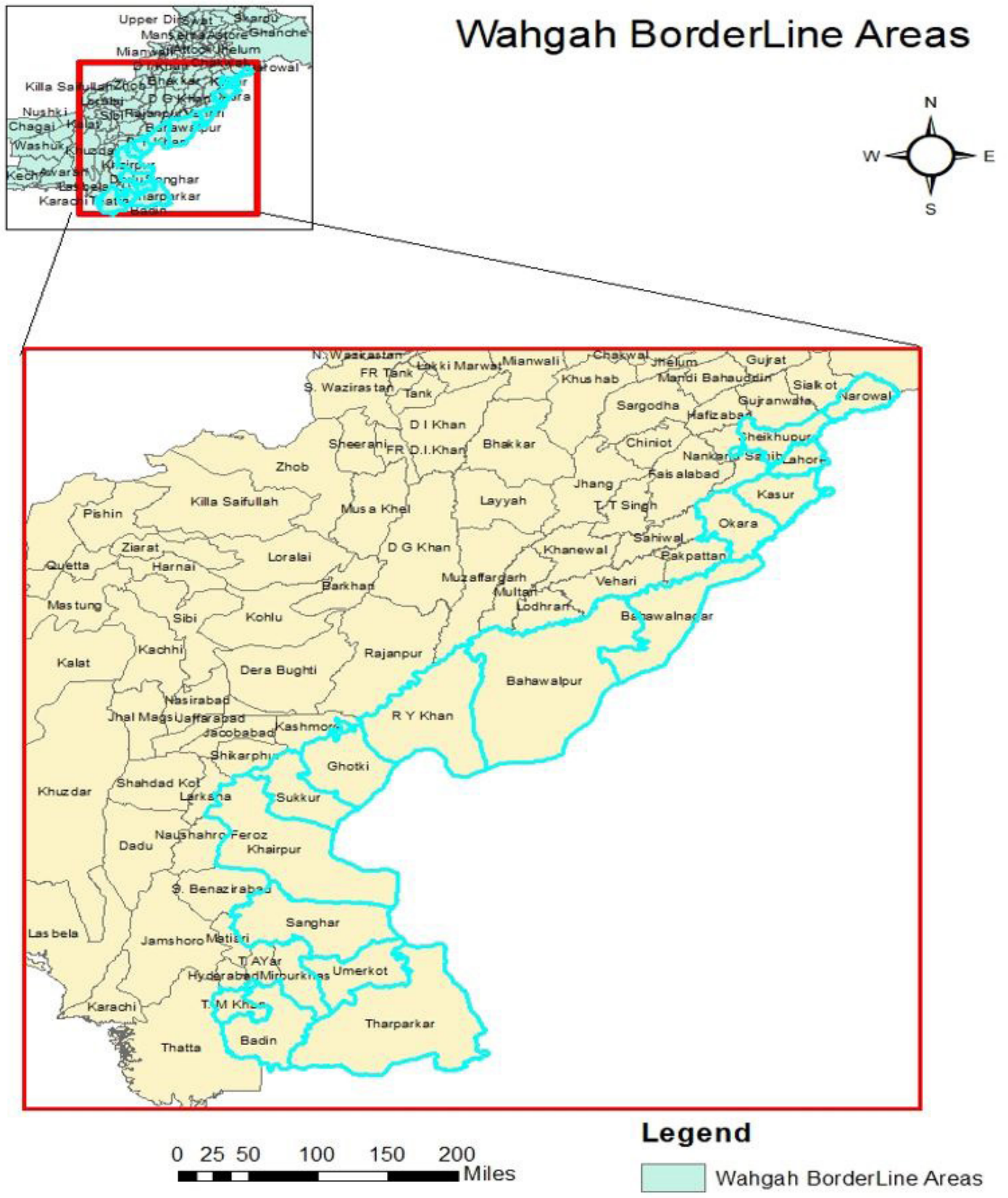

Figure 1. Map of study area.

than the cut-point of the inlet are collected on the filter media. The mass of these particulates is determined by the difference in filter weight before and after sampling. The concentration of the suspended particulate matter in the designated size range is calculated by dividing the weight gain of the filter by the volume of the air sampled. Regardless of type of sampler, they all have in common a size selective inlet, a filter or other mechanism to trap the particulates, and a means of pulling air through the system. PM 2.5 and PM 10 concentration was measured practically at Wagah border and two other sides (Jail road and Gullberg) by using MiniVol portable air sampler $\mathrm{SN}: 3224$ by this procedure for 60 minutes. Study period was of nine months, starting from 01-03-2019 to 31-12-2019. The data was collected at each sites on weekly basis. Due to some technical issues, October data can't be recorded while in study after September a sudden shift in trend was observed in November. 
Trend of variation was studied in three different sites of Lahore. Pakistan Meteorological department uses different instruments such as

* Stevenson Screen to shelter various types of temperature and humidity measuring instruments

a) Thermometer for measurement of dry bulb and wet bulb temperatures.

b) Maximum and minimum thermometer

* Mercury Filled Barometer

* Anemometer

\section{Gas flow schematics}

The ambient air enters the air pointer through sample inlet. Gas goes into the filter inlet and from there it goes into different modules where different kinds of measurements are done. Then pump draws sampling gas through modules using one or two pistons and leaves the device. Additional ambient air enters the air pointer. The zero air flows to each module. The zero air valve is integrated into each module.the temperature is controlled to avoid the effects of humidity.

\section{Gas flow of 03 analyzing module}

\section{Gas flow of $\mathrm{CO}$ analyzing module}

\section{Gas Flow of NOx analyzing module}

\section{Gas Flow of SO2 analyzing Module}

The air pointer is used in Environmental Protection Department for the measurement of ambient air quality. Air pointer is highly flexible and ideal tool for monitoring $\mathrm{CO}, \mathrm{O}_{3}, \mathrm{H}_{2} \mathrm{~S}, \mathrm{SO}_{2}, \mathrm{NO} / \mathrm{NO}_{2} / \mathrm{NO}_{\mathrm{x}}$ and PM. Data on weather parameters (total cloud amount, temperature, humidity
$\%$, temperature and pressure) was collected from Pakistan Meteorological Department and then data was statistically analyzed by comparing with pollutant's concentration (PM10, PM 2.5, CO, NO, $\mathrm{NO}_{2}, \mathrm{SO}_{2}$ and $\mathrm{O}_{3}$ ) using Pearson's correlation to find out the relationship between variables of interest in order to understand how the weather parameters contribute to the prevalence of pollutants in different manners. The Air Quality Index (AQI) is a pointer that determines the degree of pollution in an area was also-calculated from pollutants concentration.

\section{Results and Discussion}

Ambient air quality was monitored at different sites of Lahore (Jail road, Gulberg and Wagah Border). Data was collected and represented through an extension of simple line and column chart. According to our results, primary and secondary pollutants had large variations at different sites of Lahore. The weekly average of PM 2.5 showed that concentration range of PM 2.5 at Wagah border was comparatively higher $\left(72 \mu \mathrm{g} / \mathrm{m}^{3}-158 \mu \mathrm{g} / \mathrm{m}^{3}\right)$ than concentration range of PM 2.5 in ambient air of Jail road $\left(24 \mu \mathrm{g} / \mathrm{m}^{3}-176 \mu \mathrm{g} / \mathrm{m}^{3}\right)$ and Gulberg $\left(22 \mu \mathrm{g} / \mathrm{m}^{3}-80 \mu \mathrm{g} /\right.$ $\mathrm{m}^{3}$ ). In April highest concentration of PM2.5 recorded at Wagah border that is $140 \mu \mathrm{g} / \mathrm{m}^{3}$. In November and December concentration of PM 2.5 rose to $137 \mu \mathrm{g} / \mathrm{m}^{3}$ at Jail road. Whereas the compliance of results with NEQS showed that concentration of PM 2.5 was significantly above permissible limit in all areas which is $35 \mu \mathrm{g} / \mathrm{m}^{3}$ for 24 hours (Figure 2). A noticeable seasonal change in PM 2.5 mass concentration was observed in a study conducted to investigate the seasonal mass concentration level of PM2.5 in ambient air of Islamabad (Mehmood et al., 2018). Concentration of PM2.5 in above mentioned study raised in winter $(69.97 \mu \mathrm{g} / \mathrm{m} 3)$ and the atmosphere became polluted in 2017. While in our study, 2018 data was collected and similar trend was observed which showed that PM 2.5 concentration raised to higher level $(137 \mu \mathrm{g} / \mathrm{m} 3)$ in December and atmosphere became polluted because in winter, conditions get worsen due to trapping of pollutants by temperature inversion. The study of Mikuška et al. (2015) states the highest concentrations

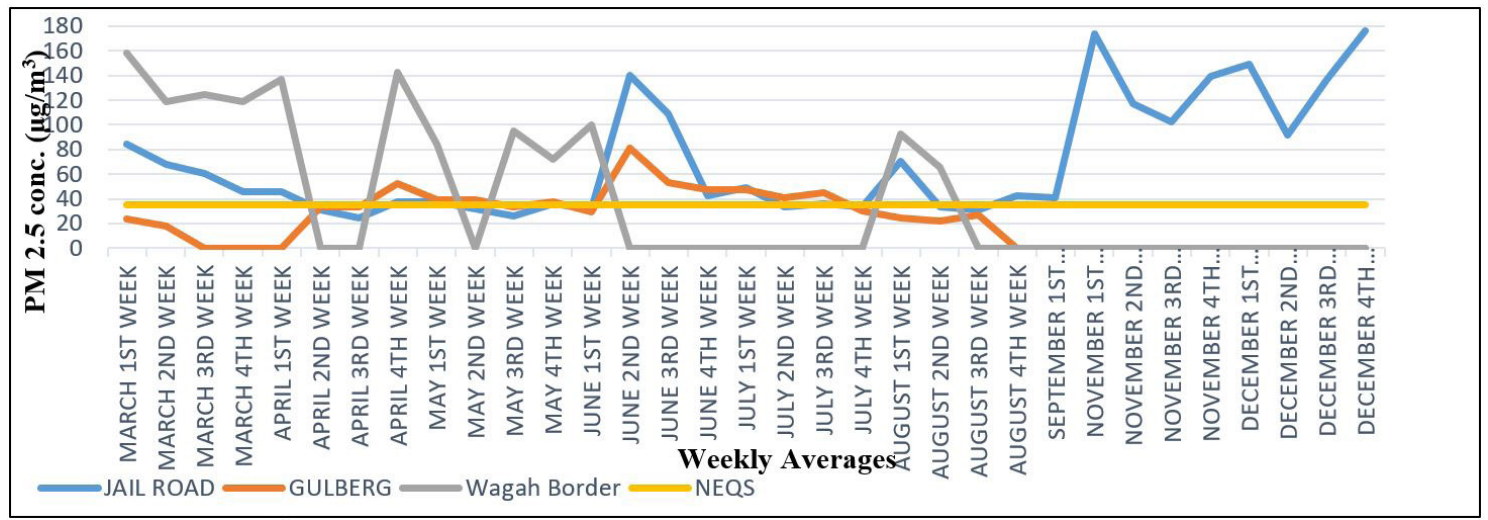

Figure 2. Weekly average concentration of PM 2.5 in ambient air of Lahore from March to December. 
of PM2.5 and bound organic compounds were found during a smog episode characterized by poor dispersion conditions. . Transboundary transport of polluted air from the Silesian Voivodeship could have contributed to the pollution in the Moravian-Silesian region during the smog episode. In Dehli and the National Capital Territory (NCT) in 2016 smog episode with air visibility of about $5 \mathrm{~km}$ or less with average PM2.5 concentrations $\left(793 \mu \mathrm{g} \mathrm{m}^{-3}\right)$ has been recorded. The study deduced to three main reasons of smog, firstly the shipping of carbonaceous substantial due to crop burning residues from October to November. The $2^{\text {nd }}$ weaker transboundary layers, cooler air and greater humidity imposing air stagnation and the $3^{\text {rd }}$ nonstop releases from fire-cracker bursting from Oct. Inspecting the timing of agricultural residues burning in Delhi causing a steady rise in severity of SMOG episodes in the recent centuries (Sawlani et al., 2019).

Weekly average of PM10 concentration in ambient air of Jail road $\left(59 \mu \mathrm{g} / \mathrm{m}^{3}-416 \mu \mathrm{g} / \mathrm{m}^{3}\right)$ was comparatively higher and in June PM10 concentration rose to highest level $\left(307 \mu \mathrm{g} / \mathrm{m}^{3}\right)$ because of heavy traffic load and commercial area. The concentration ranges of PM 10 in the ambient air of Gulberg $\left(18 \mu \mathrm{g} / \mathrm{m}^{3}-316 \mu \mathrm{g} / \mathrm{m}^{3}\right)$ was comparatively moderate. A considerable factor was that in June, highest concentration of PM10 was recorded in all areas that reach up to $307 \mu \mathrm{g} / \mathrm{m}^{3}$. Whereas the compliance of results with NEQS showed that concentration of PM 10 was significantly above the permissible limit $\left(150 \mu \mathrm{g} / \mathrm{m}^{3}\right.$ for $24 \mathrm{hr}$ ) in all areas except Gulberg (Figure 3). A research conducted by Abbas et al, 2017 in Lahore showed that transport sector is a major contributor towards air pollution, particularly in the urban areas. The vehicular congestion as well as meteorological factors had a positive association with the PM levels. PM concentrations were significantly higher than the WHO recommended levels. It is necessary to control emissions from vehicular exhaust to reduce the level of pollutants in the ambient air in urban areas (Ali et al., 2015). A similar study of Hameed et al. (2013) reveals that $70 \%$ air pollution in city is attributed to Traffic pollution. Out of which $40 \%$ is from poorly maintained auto rickshaws, pickups and diesel buses.

According to our results, weekly average of NO concentration in ambient air of Jail road $\left(4 \mu \mathrm{g} / \mathrm{m}^{3}-33 \mu \mathrm{g} / \mathrm{m}^{3}\right)$ was comparatively higher and a considerable factor was that in November and December, highest concentration of NO was recorded that reach up to $131 \mu \mathrm{g} / \mathrm{m}^{3}$. Concentration range of NO in the ambient air of Gulberg $\left(4.5 \mu \mathrm{g} / \mathrm{m}^{3}\right.$ $\left.115.4 \mu \mathrm{g} / \mathrm{m}^{3}\right)$ and Wagah border $\left(5 \mu \mathrm{g} / \mathrm{m}^{3}-96.5 \mu \mathrm{g} / \mathrm{m}^{3}\right)$ was moderate. Whereas the compliance of results with NEQS showed that concentration of NO was significantly below the permissible limit in all areas except for the months of March, April, November and December (Figure 4). Results also showed that weekly average concentration range of $\mathrm{NO}_{2}$ in ambient air of Jail road $\left(24 \mu \mathrm{g} / \mathrm{m}^{3}-141 \mu \mathrm{g} / \mathrm{m}^{3}\right)$ was

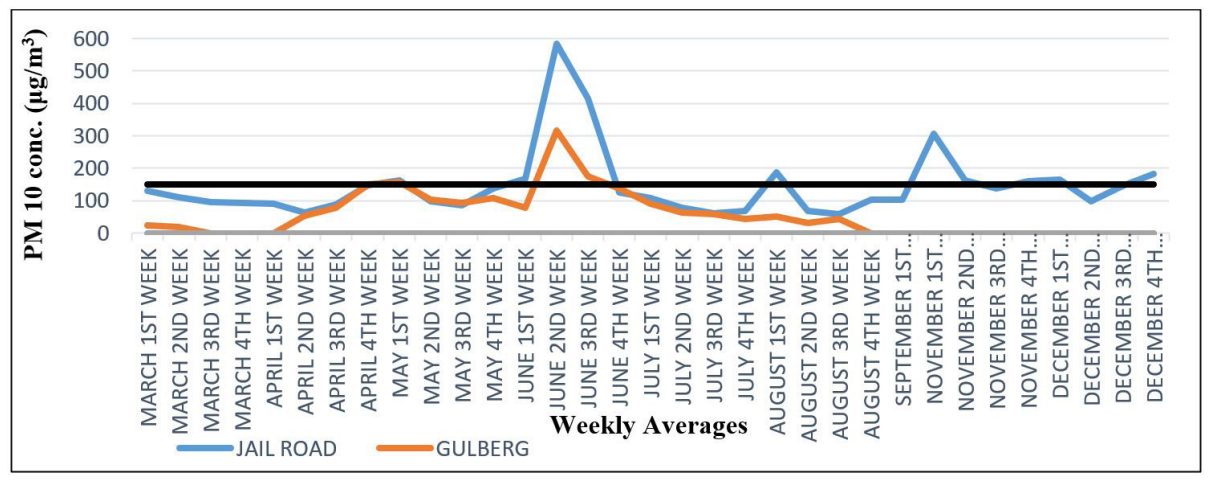

Figure 3. Weekly average concentration of PM 10 in ambient air of Lahore from March to December.

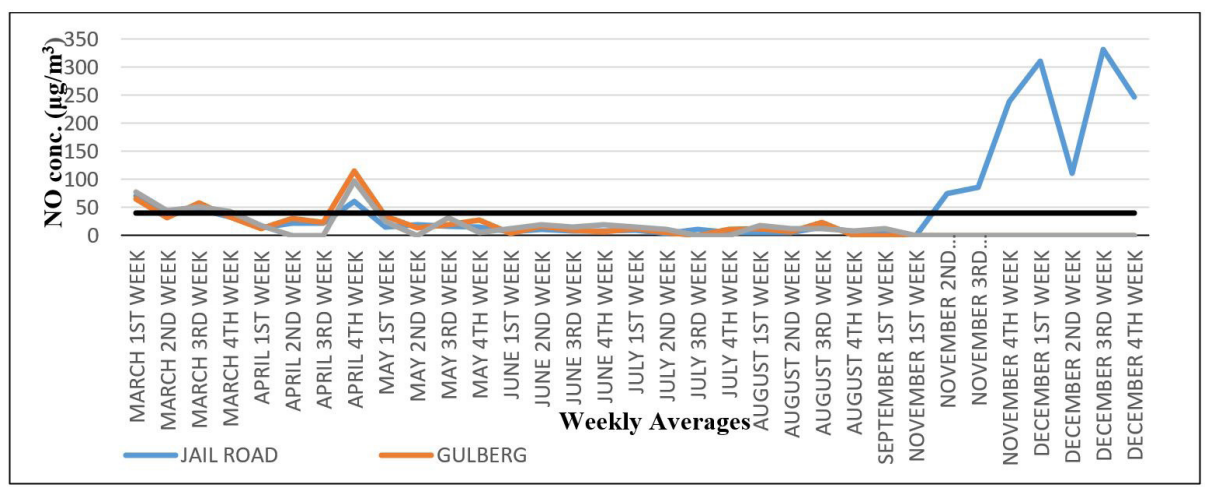

Figure 4. Weekly average concentration of NO in ambient air of Lahore from March to December. 
comparatively higher and a considerable factor was that in November and December, highest concentration of $\mathrm{NO}_{2}$ was recorded that reach up to $151 \mu \mathrm{g} / \mathrm{m}^{3}$. Concentration range of $\mathrm{NO}_{2}$ in the ambient air of Gulberg $\left(9 \mu \mathrm{g} / \mathrm{m}^{3}-73 \mu \mathrm{g} / \mathrm{m}^{3}\right)$ and Wagah border $\left(30 \mu \mathrm{g} / \mathrm{m}^{3}-104 \mu \mathrm{g} / \mathrm{m}^{3}\right)$ was moderate. Whereas the compliance of results with NEQS showed that concentration of $\mathrm{NO}_{2}$ was significantly below the permissible limit $\left(80 \mu \mathrm{g} / \mathrm{m}^{3}\right)$ in all areas except for the months of May, November and December due to worsening of weather conditions (Figure 5 ). $\mathrm{NO}_{2}$ growth over major cities of Pakistan has been studied, particularly the areas with rapid urbanization shows that $\mathrm{NO}_{2}$ are maximum in winter and minimum in summer months in Punjab and also found that $\mathrm{NO}_{2}$ emissions are dominated by anthropogenic sources (Khokhar et al., 2015). Another study of UN-ECE (1998) shows that ozone concentrations in highly polluted areas efficiently reduced by a combination of NOx and VOC controls. With low NOx concentrations, both NOx and VOC control reduces ozone levels but NOx control is more effective.

According to our results, weekly average concentration of $\mathrm{O}_{3}$ revealed that concentration range of $\mathrm{O}_{3}$ in ambient air of Gulberg $\left(8 \mu \mathrm{g} / \mathrm{m}^{3}-56 \mu \mathrm{g} / \mathrm{m}^{3}\right)$ was comparatively moderate and concentration range of $\mathrm{O}_{3}$ in the ambient air of Jail road $\left(23 \mu \mathrm{g} / \mathrm{m}^{3}-96 \mu \mathrm{g} / \mathrm{m}^{3}\right)$ was also moderate. Whereas the compliance of results with NEQS showed that concentration of $\mathrm{O}_{3}$ was significantly below the permissible limit in all areas that is $130 \mu \mathrm{g} / \mathrm{m}^{3}$ (Figure 6) and results of weekly and monthly concentration of $\mathrm{SO}_{2}$ showed that concentration range of $\mathrm{SO}_{2}$ in ambient air of Gulberg $\left(4 \mu \mathrm{g} / \mathrm{m}^{3}-59 \mu \mathrm{g} / \mathrm{m}^{3}\right.$ ) was comparatively moderate and concentration range of $\mathrm{SO}_{2}$ in the ambient air of Wagah border $\left(10 \mu \mathrm{g} / \mathrm{m}^{3}-97 \mu \mathrm{g} / \mathrm{m}^{3}\right)$ and Jail road $\left(7 \mu \mathrm{g} / \mathrm{m}^{3}-57 \mu \mathrm{g} / \mathrm{m}^{3}\right)$ was also moderate. Whereas the compliance of results with NEQS showed that concentration of $\mathrm{SO}_{2}$ was significantly below the permissible limit in all areas that is $120 \mu \mathrm{g} / \mathrm{m}^{3}$ (Figure 7 ). From combustion processes primary fine particles emitted which consisting of mixtures of many trace metal mixes and sulfuric acid mists. The secondary aerosols are organics and ammonium sulfate and nitrate formed from gaseous emissions of sulfur dioxide $\left(\mathrm{SO}_{2}\right)$ and nitrogen oxides ( $\mathrm{NOx}$ ) that react with ammonia $\left(\mathrm{NH}_{3}\right)$. Sulfur dioxide, nitrogen oxides, and ammonia are important precursors to secondary aerosols (ammonium sulfate, ammonium bisulfate, ammonium nitrate) (Belis et al., 2013; Falcon-Rodriguez et al., 2016).

In the previous study, concentration of $\mathrm{SO}_{2}$ and $\mathrm{O}_{3}$ measured at Gulberg were $118 \mathrm{ug} / \mathrm{m}^{3}$ and $212 \mu \mathrm{g} / \mathrm{m}^{3}$ and

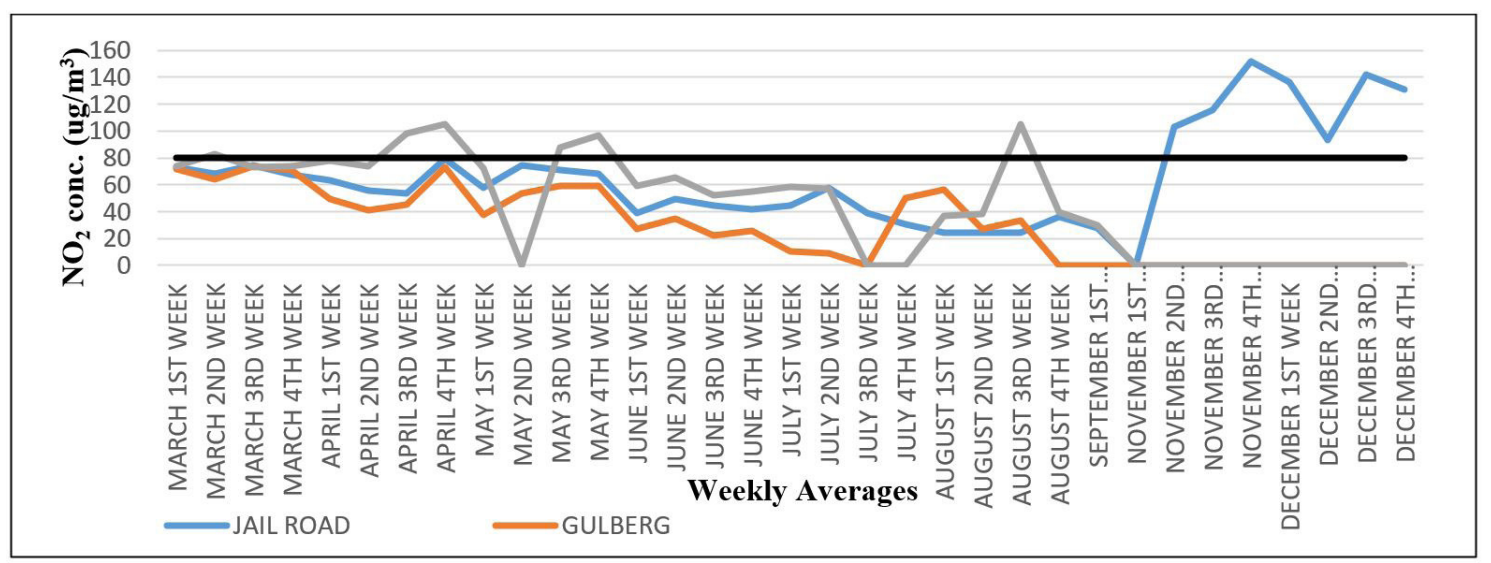

Figure 5. Weekly average concentration of NO2 in ambient air of Lahore from December to March.

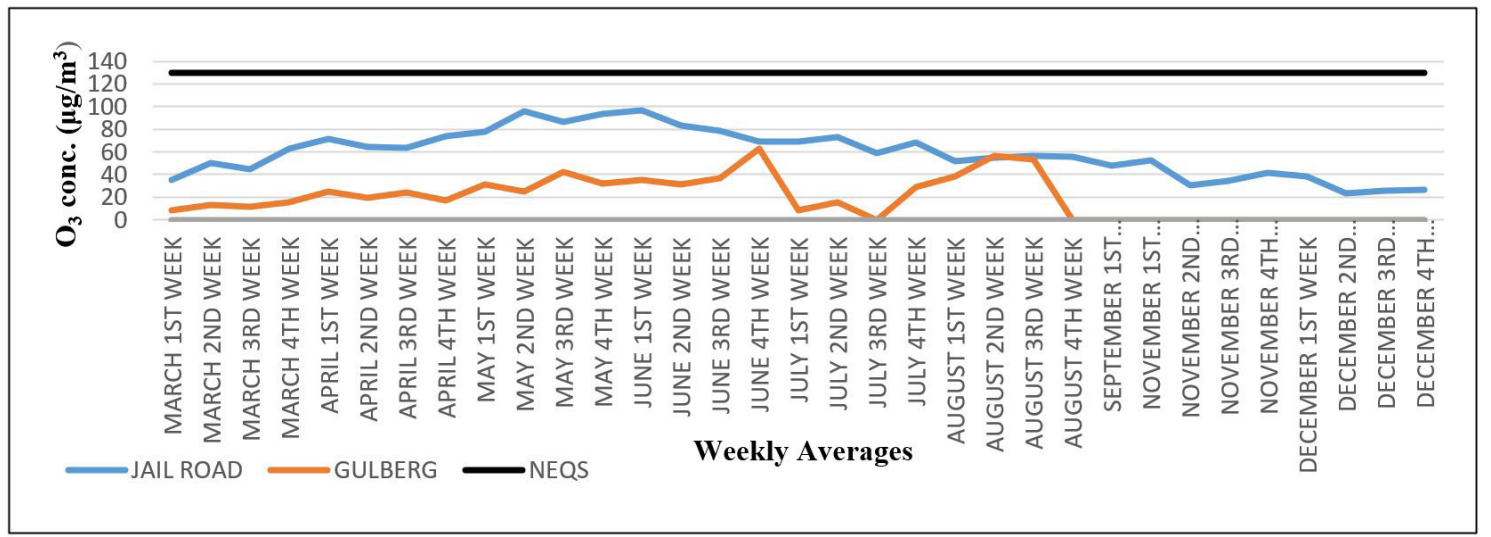

Figure 6. Weekly average concentration of $\mathrm{O} 3$ in ambient air of Lahore from Mach to December. 
value was higher than NEQS which is $120 \mathrm{ug} / \mathrm{m}^{3}$ and $130 \mu \mathrm{g} /$ $\mathrm{m}^{3}$ (Abrar et al., 2014) while in our study concentration of $\mathrm{SO}_{2}$ and $\mathrm{O}_{3}$ were below the permissible limit in all areas (Jail road, Wagah border and Gulberg) because as the federal government introduced recent federal regulations to reduce the Sulphur content of diesel fuels, this has made a significant improvement in emissions from this sector. During the study the comparison was also made between primary and secondary pollutants and meteorological conditions.

Meteorological conditions have strong influence on the persistency of pollutants in the lower troposphere. According to results, Pearson correlation showed that PM $10(\mathrm{r}=-0.4089)$, PM $2.5(\mathrm{r}=-0.7651)$, NO $(\mathrm{r}=-0.71286)$, $\mathrm{NO}_{2}(\mathrm{r}=-0.75439)$ and $\mathrm{SO}_{2}(\mathrm{r}=-0.72296)$ have negative correlation with total cloud amount and $\mathrm{O}_{3}(\mathrm{r}=0.411085)$ has positive correlation with total cloud amount (Figure 8). Pearson correlation also showed that PM $10(\mathrm{r}=0.097985), \mathrm{PM} 2.5(\mathrm{r}=0.818691)$, $\mathrm{NO}(\mathrm{r}=0.85437)$, $\mathrm{NO}_{2}(\mathrm{r}=0.876558)$ and $\mathrm{SO}_{2}(\mathrm{r}=0.539989)$ have positive correlation with pressure and $\mathrm{O}_{3}(\mathrm{R}=-0.73796)$ has negative correlation with pressure (Figure 9). Results of Pearson correlation also showed that PM $10(\mathrm{r}=-0.13248)$, PM 2.5 ( $\mathrm{r}=-0.8808), \mathrm{NO}(\mathrm{r}=-0.94595), \mathrm{NO}_{2}(\mathrm{r}=-0.87201)$ and $\mathrm{SO}_{2}(\mathrm{r}=-0.33685)$ have negative correlation with temperature and $\mathrm{O}_{3}(\mathrm{r}=0.846968)$ has positive correlation with temperature (Figure 10). A negative correlation of temperature was observed with almost all the pollutants because during winters temperature inversion occurs that results in trap of pollutants to drastic level and buildup of smog. In our study PM 10 ( $\mathrm{r}=-0.37173)$, $\mathrm{O}_{3}(\mathrm{r}=-0.5466)$ and $\mathrm{SO}_{2}(\mathrm{r}=-0.60098)$ have negative correlation with humidity and PM $2.5(\mathrm{r}=0.086825)$, $\mathrm{NO}(\mathrm{r}=0.299006)$ and $\mathrm{NO}_{2}(\mathrm{r}=0.072338)$ have positive correlation with humidity (Figure 11). Weekly trend of Air Quality Index of PM 2.5 has grown in November till december (Figure 12). Weekly trend of Air Quality Index of PM 10 has grown in $2^{\text {nd }}$ week of June and flucated in rest of the months (Figure 13).

It is observed from the present study that PM was much more responsible for smog formation. Nitrogen oxides also played role in smog formation because their concentration

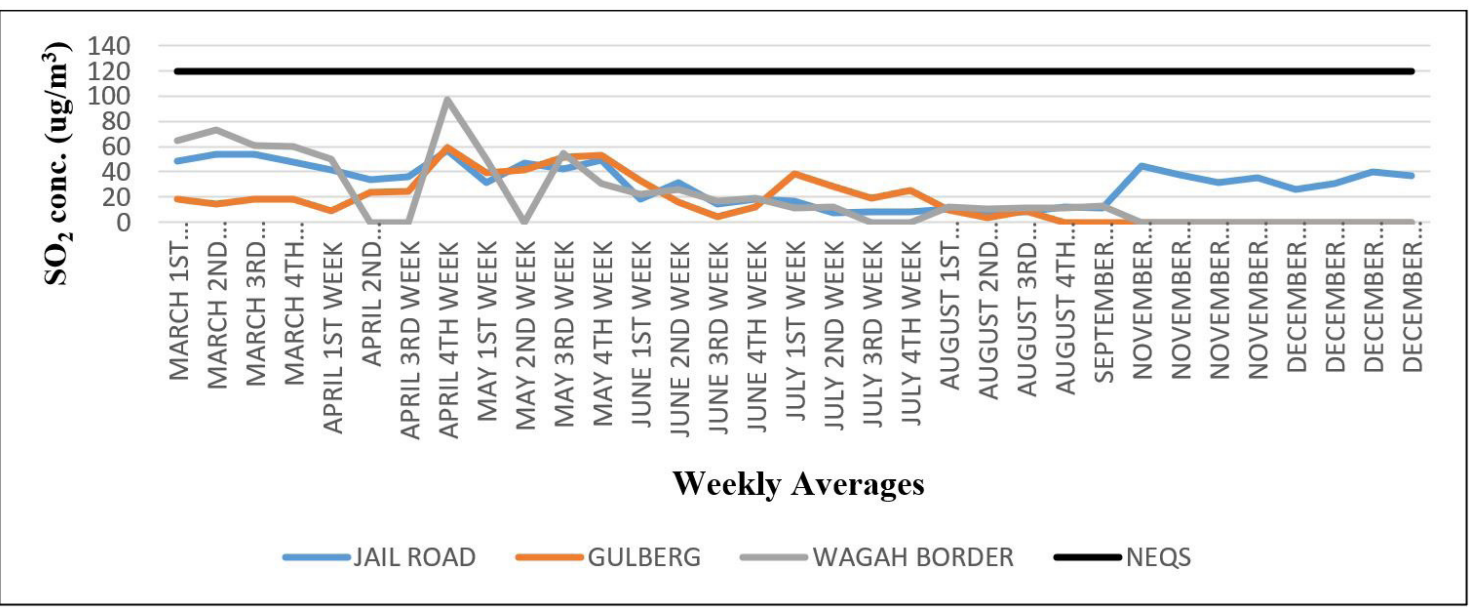

Figure 7. Weekly average concentration of SO2 in ambient air of Lahore from Mach to December.

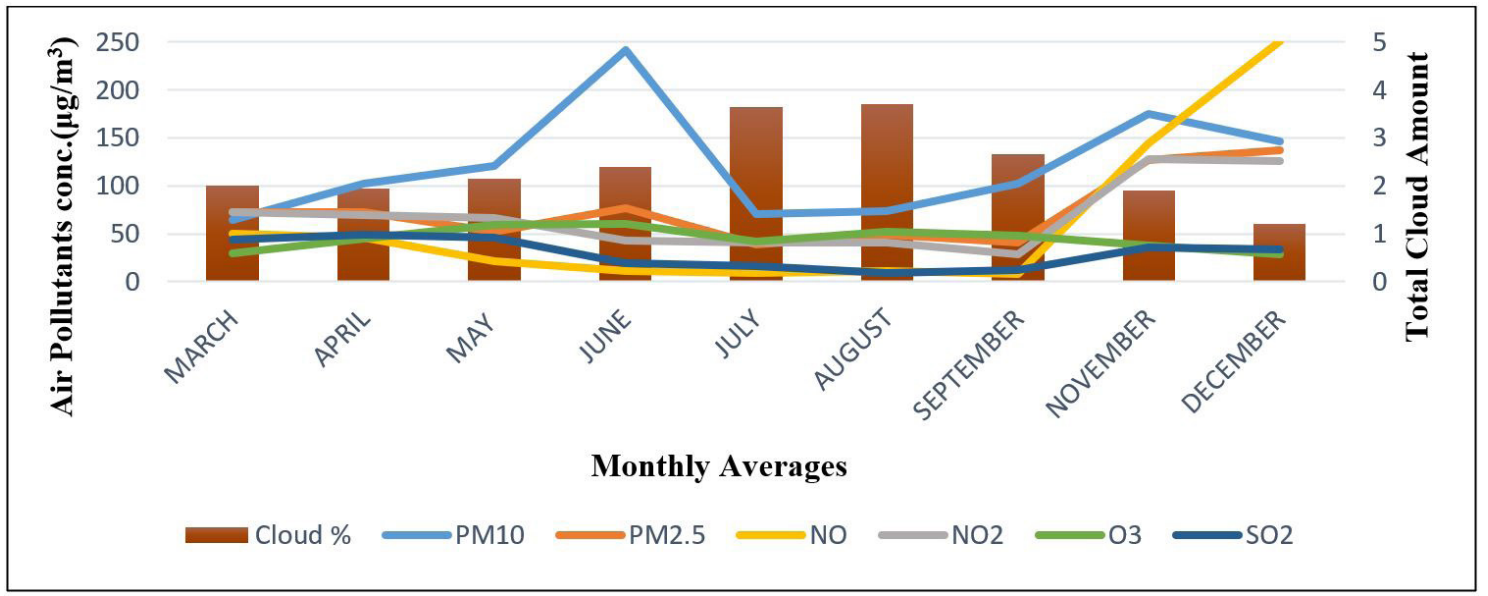

Figure 8. Correlation of air pollutants concentration with total cloud amount. 


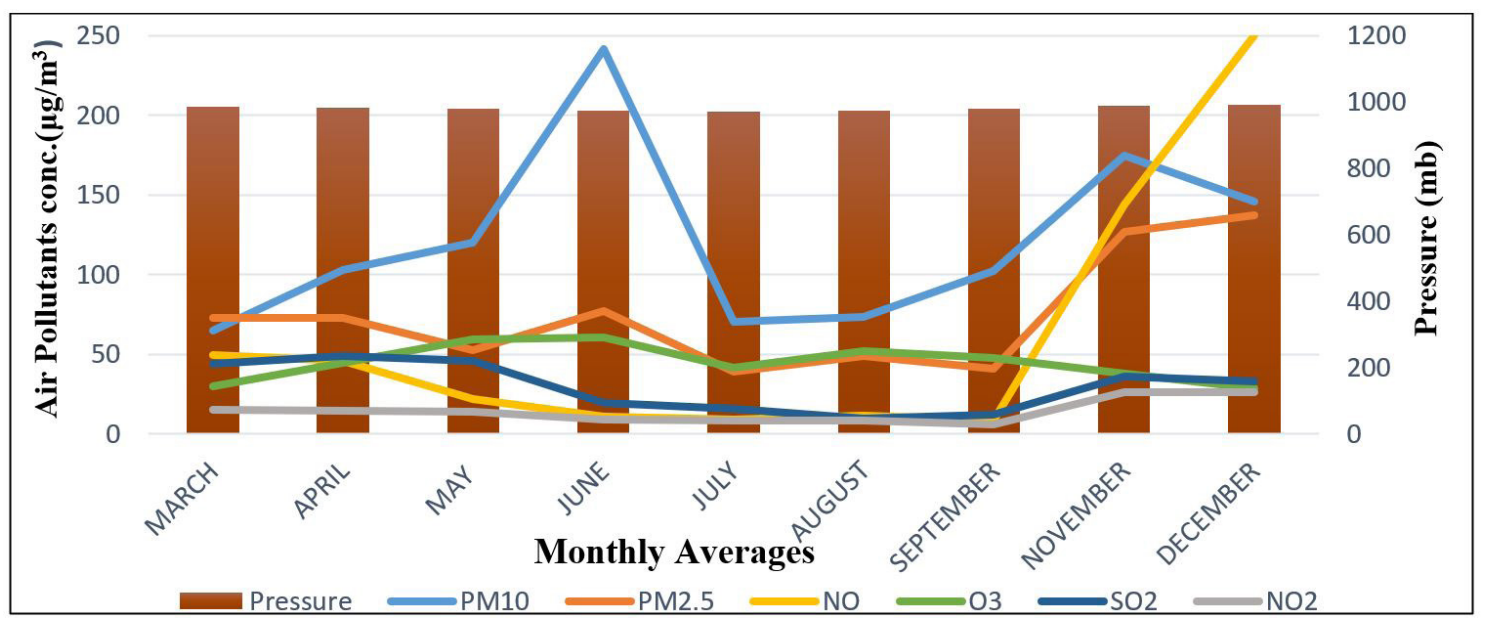

Figure 9. Correlation of air pollutants concentration with pressure.

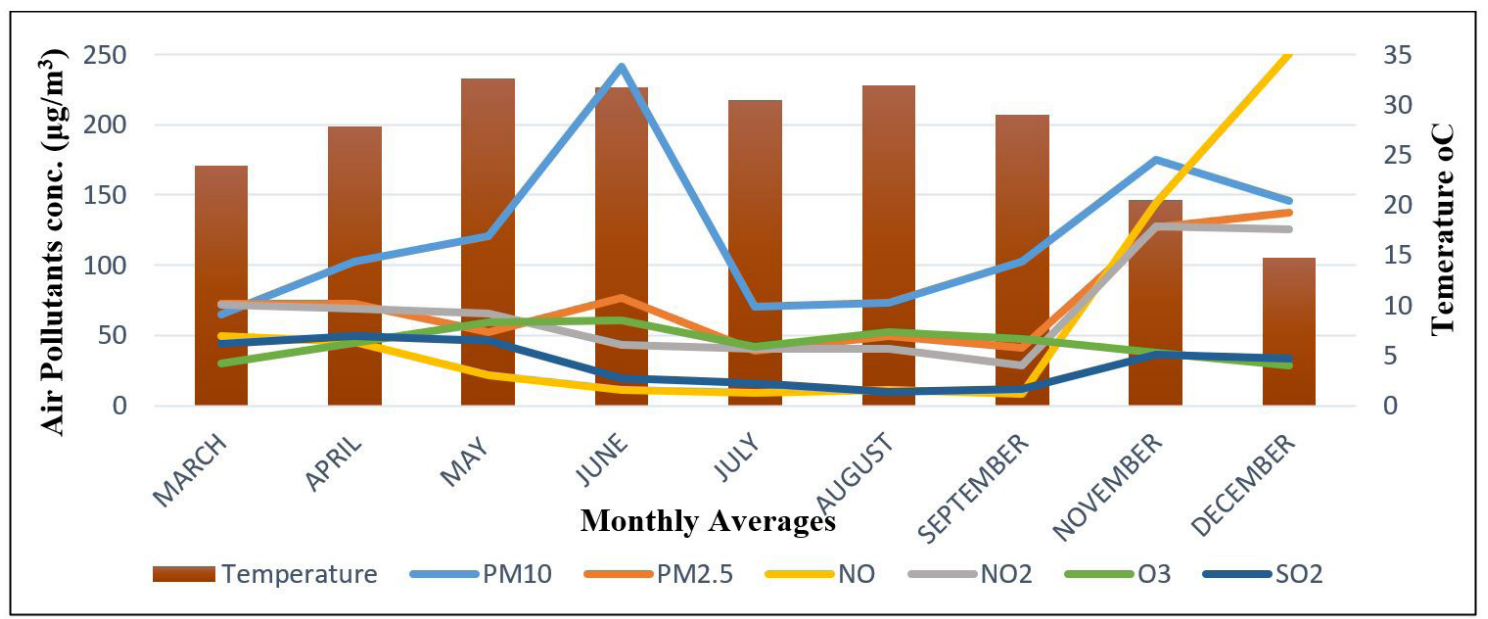

Figure 10. Correlation of air pollutants concentration with temperature.

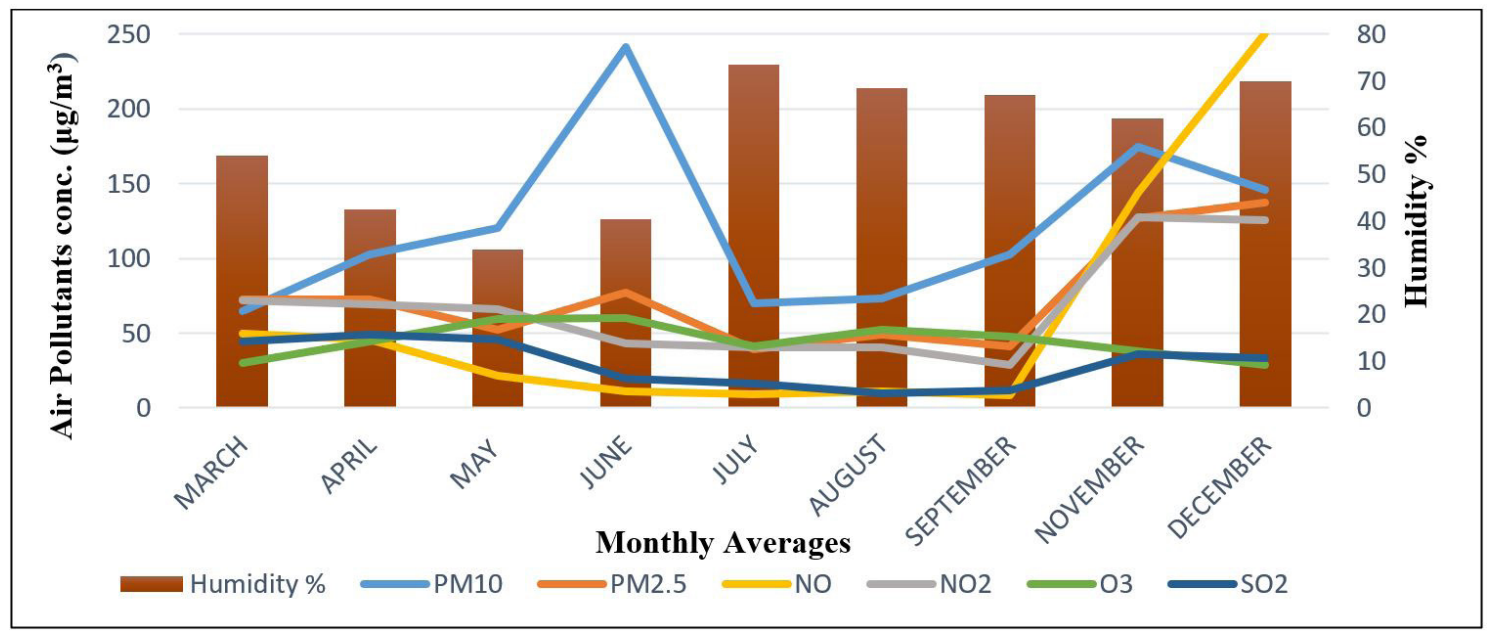

Figure 11. Correlation of air pollutants concentration with humidity percentage. 


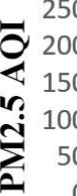

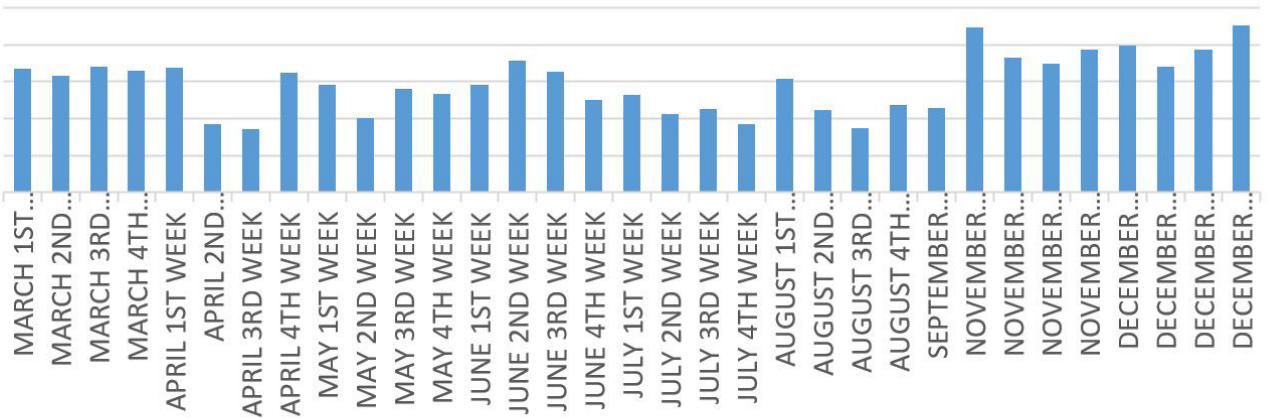

\section{Weekly Trend}

Figure 12. Weekly trend of Air Quality Index of PM 2.5.

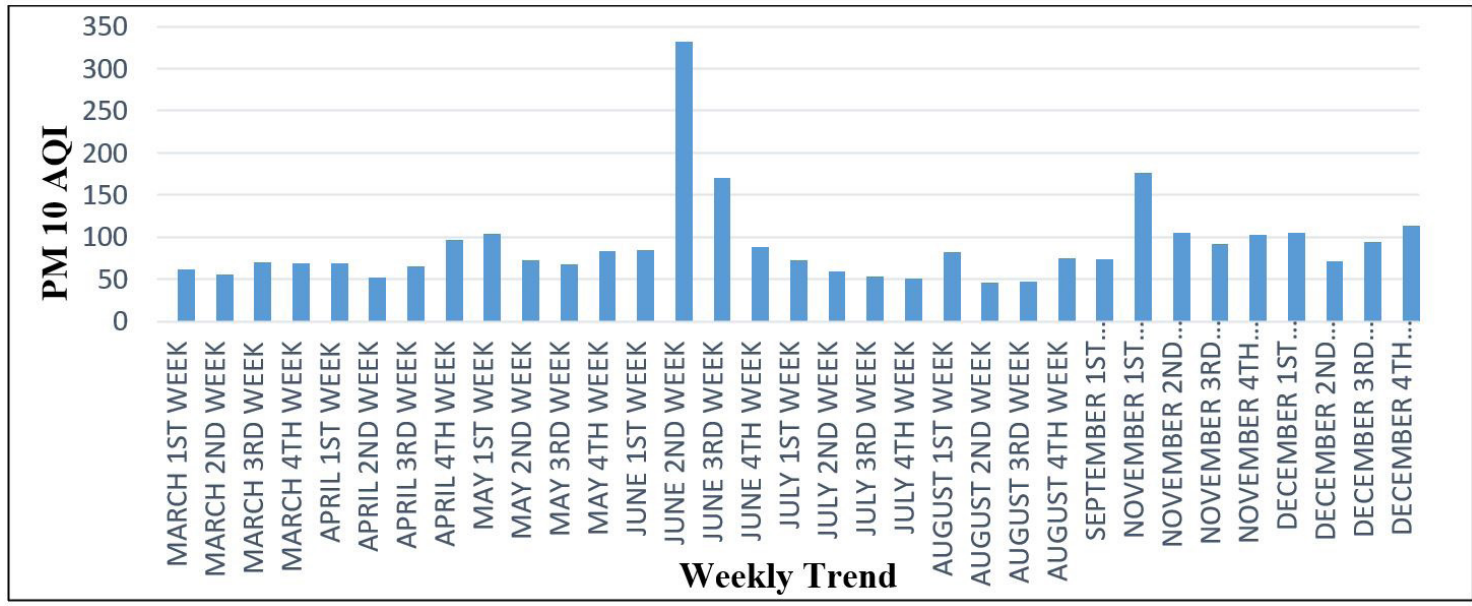

Figure 13. Weekly trend of Air Quality Index of PM 10.

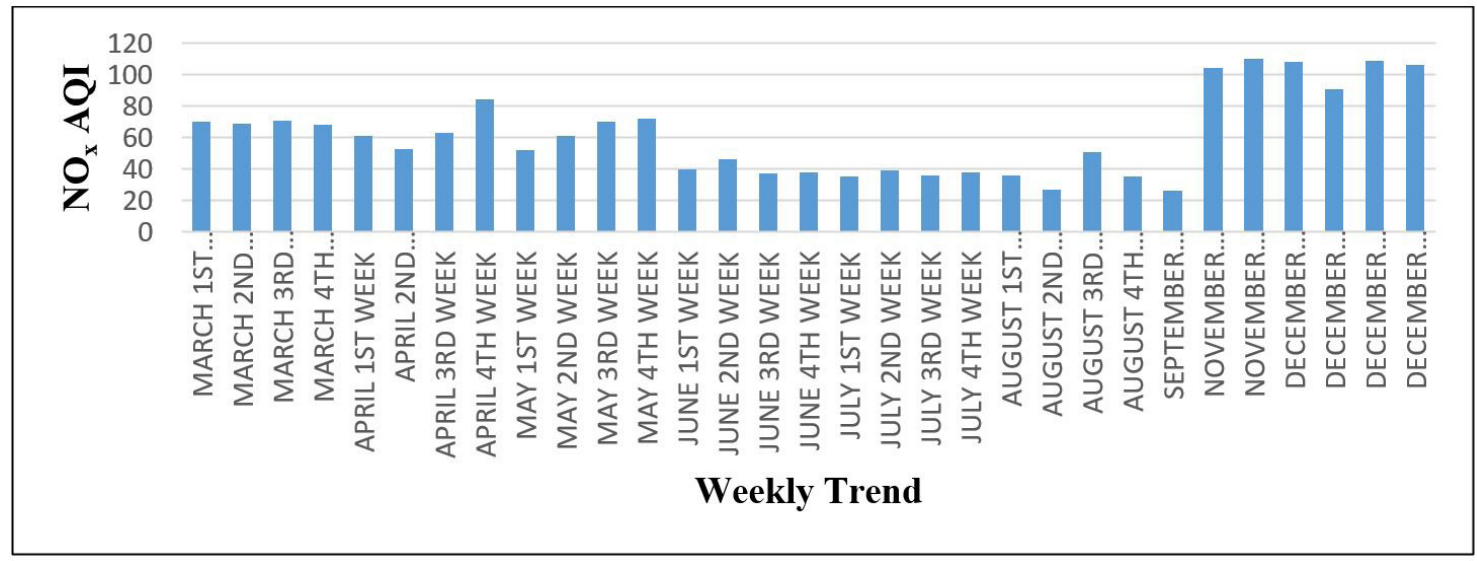

Figure 14. Weekly trend of Air Quality Index of NOx.

increases in winter (Figure 14). Sulphur dioxide and ozone played no role in smog formation (Figure 15). Therefore, there is need to pay much more attention in reducing the sources of particulate matter and nitrogen oxides in order to reduce smog formation in Lahore particularly in Wagah town.

The results of our work support the previous studies (Mushtaq et al., 2011) that particulate matter (PM) at 


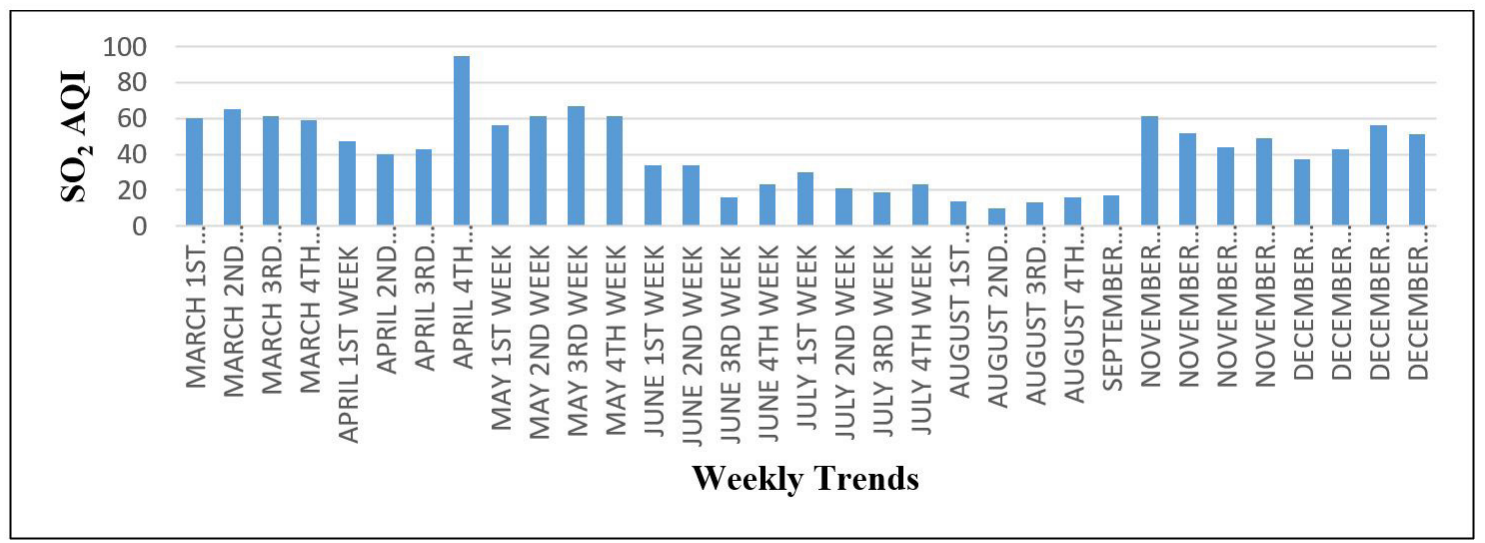

Figure 15. Weekly trend of Air Quality Index of SO2.

Wagah and NO pollution in Lahore city has become a serious problem especially in areas of high population and vehicle density and their levels were found higher in air irrespective of NEQS and USEPA standards. The variation in pollution indicator parameters were found directly related to weather conditions and the activities of respective area. As the weather conditions changed, the contents of the pollutant also changed considerably.

So the need of hour is to reduce particulate emissions on priority basis and $\mathrm{NO}_{\mathrm{x}}$ emissions in Lahore so that smog occurrence can be reduced. In order to overcome the issue, the Present study can be used as a model framework for the analysis of seasonal variations in primary and secondary pollutants and their role in smog formation. Future implementations of the study can be achieved through following recommendations.

1. Awareness campaigns about the harmful effects of particulate matter and nitrogen oxides should be made more active;

2. Government should create green spaces that help remove particulate matter and reduce the heat island effect;

3. Policies should be made by governmental and private institutions to reduce the emissions from sources especially the emissions of particulate matter and nitrogen oxides;

4. Tree plantation at the borderline areas and surroundings will be helpful to keep the environment clean as it is the sink of pollution;

5. Transboundary air pollution should be controlled by shutting down of brick Killen and burning of crops in critical periods in both sides.

\section{Conclusion}

It is concluded from the current study that primary and secondary pollutants have great seasonal variations and have great influence on smog formation. Concentrations of primary and secondary pollutants were greatly dependent upon meteorological conditions. Results showed that among all primary and secondary pollutants, PM 2.5 and PM 10 had highest concentrations at Wagah border. Concentrations of $\mathrm{NO}_{\mathrm{x}}$ were also found above the permissible limits in Wagah and Jail road and thus played role in smog formation. Results cleared that $\mathrm{O}_{3}$ and $\mathrm{SO}_{2}$ were below the permissible limits so they have no role in smog formation and there is no need to concentrate upon the mitigations to control their emissions. Therefore, air quality is deteriorating day by day in cities due to these harmful emissions particularly the transboundary air pollution and therefor provincial capital, Lahore is among the most polluted cities in the world. Air pollution caused by traffic, industries, crop burning and burning of solid waste are the major contributors of smog and the layer of smog will thicken in the coming days. So, urgent action needs to be taken to tackle this issue and policies should be made by governmental and private institutions to reduce the emissions from sources especially the emissions of particulate matter and nitrogen oxides in order to reduce smog pollution in Lahore.

\section{Acknowledgements}

We acknowledge the support of Environmental Protection Department, Punjab and Meteorological Department Lahore, Pakistan.

\section{References}

ABBAS, M., TAHIRA, A., JAMIL, S., ABRAR, A. and RASHID, F., 2017. Air quality monitoring of particulate matter (pm $2.5 \&$ pm 10) at niazi and daewoo bus station. Lahore FUUAST Journal of Biology, vol. 7, no. 1, pp. 13-18.

ABRAR, A., SUNDAS, W., PERVEEN, F. and HABIB, M., 2014. Air quality monitoring of some gaseous pollutants at selected points in Gullberg II, Lahore, Pakistan. International Research Journal of Environment Sciences, vol. 3, no. 6, pp. 38-47.

ALI, Z., RAUF, A., SIDRA, S., NASIR, Z.A. and COLBECK, I., 2015. Air quality(particulate matter) at heavy traffic sites in Lahore, Pakistan. The Journal of Animal \& Plant Sciences, vol. 25, no. 3, suppl. 2, pp. 644-648.

BELIS, C.A., KARAGULIAN, F., LARSEN, B.R. and HOPKE, P.K., 2013. Critical review and meta-analysis of ambient particulate 
matter source apportionment using receptor models in Europe. Atmospheric Environment, vol. 69, pp. 94-108. http://dx.doi. org/10.1016/j.atmosenv.2012.11.009.

DAVIS, D.L., BELL, M.L. and FLETCHER, T., 2002. A look back at the London smog of 1952 and the half century since. Environmental Health Perspectives, vol. 110, no. 12, pp. A734-A135. http:// dx.doi.org/10.1289/ehp.110-a734. PMid:12501843.

FALCON-RODRIGUEZ, C.I., OSORNIO-VARGAS, A.R., SADA-OVALLE, I. and SEGURA-MEDINA, P., 2016. Aeroparticles, composition, and lung diseases. Frontiers in Immunology, vol. 7, pp. 3. http:// dx.doi.org/10.3389/fimmu.2016.00003. PMid:26834745.

GARELNABI, M., PRUM, T., BRESNAHAN, E. and UZOIGWE, J.C., 2013. The emerging role of outdoor and indoor air pollution in cardiovascular disease. North American Journal of Medical Sciences, vol. 5, no. 8, pp. 445-453. http://dx.doi. org/10.4103/1947-2714.117290. PMid:24083218.

HAMEED, R., BHATTI, N.A., NADEEM, O., HAYDAR, S. and KHAN, M.A., 2013. Comparative analysis of emissions from motor vehicles using LPG, CNG and Petrol as Fuel in Lahore. Journal of the Chinese Institute of Chemical Engineers, vol. 41, no. 1, pp. 59-66.

HAMEED, S., MIRZA, M.I., GHAURI, B.M., SIDDIQUI, Z.R., JAVED, R., KHAN, A.R., RATTIGAN, O.V., QURESHI, S. and HUSAIN, L., 2000. On the sources of widespread winter fog in Northern Pakistan and India. Geophysical Research Letters, vol. 27, no. 13, pp. 1891-1894. http://dx.doi.org/10.1029/1999GL011020.

KHOKHAR, M.F., YASMIN, N., FATIMA, N., BEIRLE, S. and WAGNER, T., 2015. Detection of trends and seasonal variation in tropospheric nitrogen dioxide over Pakistan. Aerosol and Air Quality Research, vol. 15, no. 1, pp. 2508-2524. http://dx.doi. org/10.4209/aaqr.2015.03.0157.

MEHMOOD, K., CHANG, S., YU, S., WANG, L., LI, P., LI, Z., LIU, W. ROSENFELD, D. and SEINFELD, J.H., 2018. Spatial and temporal distributions of air pollutant emissions from open crop straw and biomass burnings in China from 2002 to 2016. Environmental Chemistry Letters, vol. 16, no. 1, pp. 301-309. http://dx.doi. org/10.1007/s10311-017-0675-6.

MIKUSKA, P., KŘŮMAL, K. and VEČEŘA, Z., 2015. Characterization of organic compounds in the PM2.5 aerosols in winter in an industrial urban area. Atmospheric Environment, vol. 105, pp. 97-108. http://dx.doi.org/10.1016/j.atmosenv.2015.01.028.

MUKHTAR, F., 2018. The rising menace of smog: time to act now. Journal of Ayub Medical College, Abbottabad: JAMC, vol. 30, no. 1, pp. 1-2. PMid:29504318.

MUSHTAQ, M., SULTANA, B., IQBAL, M. and ASHRAF, N., 2011. Evaluation of ambient air quality in Lahore, Pakistan. Pakistan Journal of Urban Affairs, vol. 1, no. 3, pp. 5-12.

RASHEED, A., ANEJA, V.P., AIYYER, A. AND RAFIQUE, U. (2015). Measurement and Analysis of Fine Particulate Matter (PM2.5) in Urban Areas of Pakistan. Aerosol Air Qual. Res., 15: 426-439. https://doi.org/10.4209/aaqr.2014.10.0269.

SÁNCHEZ-TRIANA, E., AFZAL, J., BILLER, D. and MALIK, S., 2013. Priority environmental issues associated with freight transport. Washington: World Bank Group. Greening growth in pakistan through transport sector reforms: a strategic environmental, poverty, and social assessment, pp. 83-105.

SÁNCHEZ-TRIANA, E., ENRIQUEZ, S., AFZAL, J., NAKAGAWA, A. and KHAN, A.S., 2014. Cleaning Pakistan's air: policy options to address the cost of outdoor air pollution. Washington, DC: The World Bank, pp. 57-81.

SAWLANI, R., AGNIHOTRI, R., SHARMA, C., PATRA, P.K., DIMRI, A.P., RAM, K. and VERMA, R.L., 2019. The severe Delhi SMOG of 2016: a case of delayed crop residue burning, coincident firecracker emissions, and atypical meteorology. Atmospheric Pollution Research, vol. 10, no. 3, pp. 868-879. http://dx.doi. org/10.1016/j.apr.2018.12.015.

SUGHIS, M., NAWROT, T.S., IHSAN-UL-HAQUE, S., AMJAD, A. and NEMERY, B., 2012. Blood pressure and particulate air pollution in schoolchildren of Lahore, Pakistan. BMC Public Health, vol. 12, no. 378, pp. 2-8. http://dx.doi.org/10.1186/1471-2458-12378. PMid:22632576.

TANVEER, Z., ILYAS, H., AKHTAR, S.N. and SHAFFIQUE, K., 2015. Outdoor air pollution: a case study of Gujrat City. Global Journal of Environmental Science and Management, vol. 3, no. 2, pp. 57.

UN-ECE, 1998 [viewed 22 May 2021]. Convention on long-range transboundary air pollution [online]. Geneva: UN-ECE. Available from: http:// www.unece.org/env/lrtap_h.htm 